\author{
L.S. Egorova, E.A. Leites* \\ Altai State University, Barnaul, Russia \\ (Corresponding author's e-mail: leites-elena@yandex.ru)
}

\title{
Extraction-photometric determination of osmium using quaternary water-thiopyrine-trichloroacetic and orthophosphoric acid system
}

\begin{abstract}
The article is devoted to the extraction-photometric determination of osmium. The aim was to modify the well known extraction-photometric determination of osmium by replacing chloroform, used as an organic solvent in a traditional extraction system, on to water, which is the only liquid component in the layering system. This made it possible to eliminate the toxic organic solvent from the system. The optimal conditions for the osmium extraction were selected, taking with the fact that the consumption of thiopyrine, as an expensive reagent, should be minimal. The results of the developed methodology for determining microgram amounts of osmium with thiopyrine were presented by the example of a model mixture corresponding to the composition of a platinum sponge. The interfering effect of $\mathrm{Al}$ (III), B (III), Bi (III), Fe (III), Au (III), Ir (II), Cd (II), $\mathrm{Co}$ (II), Ca (II), Si (IV), Mg (II), Mn (II), Cu (II), Mo (VI), As (V), Ni (II), Sn (IV), Pd (II), Rh (II), Pb (II), $\mathrm{Ag}$ (I), $\mathrm{Sb}$ (III), Te (IV), Cr (III), Zn (II) contained in a platinum sponge was investigated. The interfering effect of copper has been established, which is eliminated by masking with ascorbic acid.
\end{abstract}

Key words: osmium, thiopyrine, extraction-photometric determination, platinum sponge, complexation, synthesis of drugs, cortisone.

\section{Introduction}

Osmium is used to create particularly durable alloys, in the manufacture of hands and axes for measuring equipment, clockworks, and the production of drugs, for example, the cortisone. The high catalytic ability of osmium is used in chemistry and petrochemistry, osmium tetroxide is employed in the synthesis of drugs, and its alloy with platinum is used in the manufacture of cardiac implants, pacemakers and valves.

There are gravimetric, titrimetric, electrochemical methods for the determination of osmium [1-3]. The spectrophotometric methods with organic reagents of various classes are most usually used: thiourea and its derivatives, selenourea, derivatives of mercapto and nitrosoquinolines, aromatic amines, amino alcohols, amino acids, various heterocyclic compounds with various functional and analytical groups $(=\mathrm{S},-\mathrm{SH},-\mathrm{OH}$, $\left.-\mathrm{NH}_{2},=\mathrm{NH}, \equiv \mathrm{N}\right)[4]$. Alkali metal and ammonium thiocyanates are used as the inorganic reagents. Osmium is determined by own color of osmium (VI) hexabromide, and by the color of $\mathrm{OsO}_{4}$ in an organic solvent. None of the methods makes it possible to determine osmium in the presence of all the accompanying elements of the platinum group; therefore, it is separated in the form of $\mathrm{OsO}_{4}$ either by selective distillation or by selective extraction. These methods allow to concentrate osmium simultaneously. The most sensitive methods include methods for the determination of osmium using 1,5-diphenylcarbohydrazide, 1-naphthalene-4,6,8-trisulfonic acid and anthranilic acid. Very small amounts of osmium from 0.001 to $0,1 \mu \mathrm{g} / \mathrm{ml}$ are determined with the simultaneous use of sulfanilic acid and dimethylamine. Dithiocarbamic acid derivatives are suitable for the osmium determination in the presence of an excess of platinum, palladium, iron, and some other elements [5].

Thiopyrine (TP) and its derivatives form green complexes with Ru (IV) and Os (IV, VIII). The complexes of osmium with thiopyrine and its derivatives well extracted with chloroform in the presence of thiocyanate or trichloroacetate ions [6].

The goal was to modify the well known extraction-photometric determination of osmium by replacing chloroform, used as an organic solvent in a traditional extraction system, on to water, which is the only liquid component in the layering system.

\section{Experimental}

Reagents. 6.4 M TCAA and 8.7 $\mathrm{M} \mathrm{H}_{3} \mathrm{PO}_{4}, \mathrm{OsO}_{4}$ solutions, crystalline thiopyrine were used.

\footnotetext{
${ }^{*}$ Corresponding author
} 
Equipment. The absorption spectrum of the complex in the extract was taken with respect to the reference solution on a spectrophotometer «Spekol-10» in a quartz cuvette with $l=1 \mathrm{~cm}$.

Experimental methodology. The extraction-photometric determination of osmium in a quaternary system without an organic solvent has been studied. It was necessary to choose the optimal conditions for its extraction. The consumption of thiopyrine, as an expensive reagent, should be minimal. The choice of the optimal ratio of acids was carry out by the method of isomolar series.

6.4 M TCAA and $8.7 \mathrm{M} \mathrm{H}_{3} \mathrm{PO}_{4}$ solutions in various ratios were place in a series of tubes, taking into account that the total volume of the system should not exceed $5 \mathrm{ml}$. As a result, it was found that sufficient for practical purposes volume of the organic phase is equal to $2 \mathrm{ml}$. It can be obtained when the volume ratio of acid solutions is $2.5 \mathrm{ml}$ of TCAA and $2.5 \mathrm{ml}$ of $\mathrm{H}_{3} \mathrm{PO}_{4}$, i.e. $16.0 \mathrm{mmol}$ TCAA and $21.8 \mathrm{mmol}_{3} \mathrm{PO}_{4}$ or at 8:11 molar ratio of acids.

TCAA, $20 \mu \mathrm{g}$ of Os (VIII) and $30 \mathrm{mg}$ of thiopyrine were placed in a test tube in the above ratio to take the absorption spectrum of the extract. The absorbance of the green-colored extract was measured after phase separation. Containing all the starting components except osmium solution was used as a comparison solution.

\section{Results and Discussion}

The maximum light absorption of the complex was observed at $\chi=728 \mathrm{~nm}$. The optical characteristics of the extract are similar to the optical characteristics of the complex of osmium with thiopyrine in aqueous solutions and in chloroform [6].

The reaction of forming a colored compound requires a certain excess of complexing reagent. In some cases, it is sufficient to introduce a small excess (20-30\%) of the reagent compared with the stoichiometrically calculated amount for the complete binding of metal ions to the colored compound. In other cases, a significant excess of reagent is needed when the stability of the colored complex is small. So the optimal amount of reagent has been established. The obtained dependence is shown in Figure 1, from which it can be see that the absorbance of the extract reaches a maximum at $0.12 \mathrm{mmol}$ of thiopyrine. All further studies were performed with an amount of thiopyrine equal to $0.15 \mathrm{mmol}$.

Verification of compliance with the basic law of light absorption of the extract was carry out under the selected optimal conditions: $21.8 \mathrm{mmol} \mathrm{TCAA,} 16.0 \mathrm{mmol} \mathrm{H}_{3} \mathrm{PO}_{4}, 0.15 \mathrm{mmol}$ thiopyrine, a variable amount of osmium (VIII). The total volume of the system was $5.0 \mathrm{ml}$, the volume of the organic phase was $2.0 \mathrm{ml}$. The comparison solutions were prepared in a similar way.

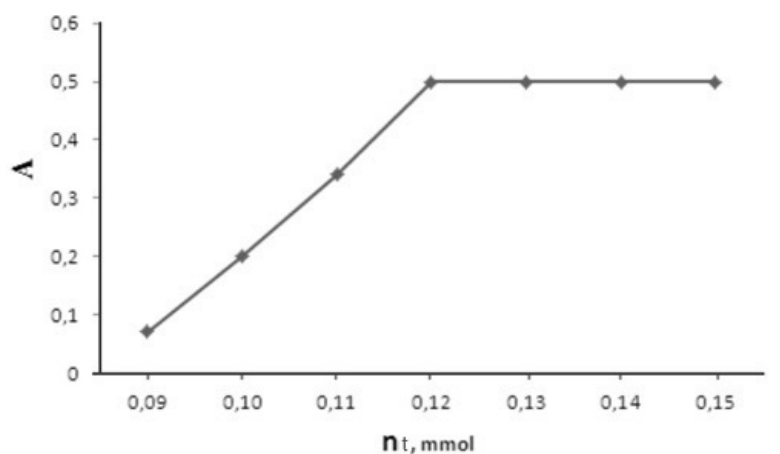

Figure 1. Dependence of the absorbance of the extract of the Os (VIII) with thiopyrine complex on the thiopyrine $(\mathrm{t})$ amount

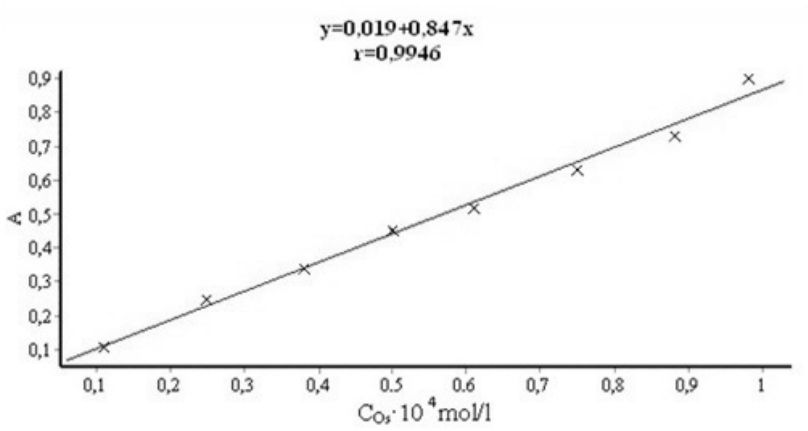

Figure 2. Calibration graph of the extraction-photometric determination of Os (VIII) with thiopyrine in the water thiopyrin - trichloroacetic acid — orthophosphoric acid tetra-quaternary system

Figure 2 shows the dependence of the absorbance of the extract of the osmium content. A linear relationship was observed when 2 to $40 \mu \mathrm{g}$ of osmium introduced into the system. This linear relationship is actually a calibration curve line for the extraction-photometric determination of osmium. The calibration graph parameters were calculated using the least squares method. The values for the linear equation parameters $y=a x+b$ (there $a$ and $b$ are coefficients, $r$ is the correlation coefficient, $S_{a}, S_{b}, S_{0}$ are the standard deviations of the $a, b$ and $r$ parameters) are given in Table 1 . 
Calculation of the calibration graph equation parameters

\begin{tabular}{|c|c|c|c|c|c|}
\hline$a$ & $S_{a}$ & $b$ & $S_{b}$ & $r$ & $S_{0}$ \\
\hline $8.8 \cdot 10^{3}$ & $2.3 \cdot 10^{-2}$ & $1.2 \cdot 10^{-3}$ & $3.6 \cdot 10^{2}$ & 0.995 & $2.9 \cdot 10^{-2}$ \\
\hline
\end{tabular}

The Os:R molar ratios of 1:4 with TP and 1:2 with dithiopyrilmethane (DTM) were established using the equilibrium shift method. The absorption increases with an increase in the excess of reagent and its maximum value is reached at a thirtyfold excess of thiopyrine. The color of the solutions is stable over time. Law of Beer is observed for $1-20 \mu \mathrm{g} / \mathrm{ml}$ Os. The complexes of osmium with thiopyrine and its derivatives well extracted with chloroform in the presence of thiocyanate or trichloroacetate ions. The light absorption curve line has a maximum at $690 \mathrm{~nm}$ in the presence of trichloroacetic acid (TCAA). Law of Beer is valid for $1.5-30 \mu \mathrm{g} / \mathrm{ml}$ osmium, the concentration of TCAA in the solution should be at least $0.05 \mathrm{M}$. Extractionphotometric determination differs from photometric because it allows to determine the Os in the presence of significant amounts of $\mathrm{Ru}$ (even at 1:100 ratio of Os:Ru). Definition of $30 \mathrm{mg} / \mathrm{ml}$ of osmium does not interfere with 5-fold amounts of $\mathrm{Al}$ (III), Cd (II), Co (II), Cr (III), Fe (III), Mg (II), Mn (II), Ni (II), Pd (II), Ti (IV) and Zn (II), 10-fold amounts of Rh, equal amounts of Pt [6].

The experimental values of the calibration graph points were used to calculate $\varepsilon_{\text {app }}$. The obtained value $\varepsilon_{\text {app }}$ equal to $8.9 \cdot 10^{3}$ slightly differs from $\varepsilon_{\text {app }}=6.3 \cdot 10^{3}$ specified in [6] due to a significant change in the composition and properties of the extract.

Well-known Asmus and Bent-French methods were used to determine the Os:TP ratio in the extraction complex [7]. Coincident ratios Os:TP $=1: 4$ in the complex were obtained, which is consistent with published data.

Osmium is found in such various objects as platinum sponge, copper-nickel-sulfide ores, etc. A model mixture corresponding to the composition of the platinum sponge was chosen to develop the method for determining osmium with thiopyrine. The osmium content in it is $(8-800) \cdot 10^{-4} \%$. Other impurities $\left(n \cdot 10^{-4}\right)$ are also contained in the platinum sponge: $\mathrm{Ag}-200 ; \mathrm{Al}-100 ; \mathrm{As}-200 ; \mathrm{Au}-100 ; \mathrm{Ir}-20$; $\mathrm{Ca}-40$; $\mathrm{Cd}$ - 100; $\mathrm{Co}-500 ; \mathrm{Cr}-40 ; \mathrm{Cu}-20 ; \mathrm{Fe}-100 ; \mathrm{Mg}-100 ; \mathrm{Mn}-40 ; \mathrm{Mo}-100 ; \mathrm{Ni}-40$; $\mathrm{Os}-800 ; \mathrm{Pb}-200 ; \mathrm{Sb}-50 ; \mathrm{Si}-100 ; \mathrm{Sn}-50 ; \mathrm{Tl}-500 ; \mathrm{Zn}-500$.

The influence of foreign ions on the results of the $10 \mu \mathrm{g}$ osmium determination was studied, since other elements besides osmium are present in the form of impurities in the platinum sponge. The 3-5\% deviation of the extract absorbance from its value, measured when determining osmium without an extraneous ion, was taken as an influence criterion (Table 2).

Table 2

Influence of interfering ions on the osmium determination

\begin{tabular}{|c|c|c|c|}
\hline Interfering ion & $\mathrm{m}_{\text {ion }} / \mathrm{m}_{\mathrm{Os}}$ & Interfering ion & $\mathrm{m}_{\text {ion }} / \mathrm{m}_{\mathrm{Os}}$ \\
\hline $\mathrm{Al}$ (III) & 20 & $\mathrm{Mo}$ (VI) & 20 \\
$\mathrm{~B}$ (III) & 10 & $\mathrm{As}$ (V) & 50 \\
$\mathrm{Bi}$ (III) & 5 & $\mathrm{Ni}$ (II) & 10 \\
$\mathrm{Fe}$ (III) & 20 & $\mathrm{Sn}$ (IV) & 13 \\
$\mathrm{Au}$ (III) & 20 & $\mathrm{Pd}$ (II) & 5 \\
$\mathrm{Ir}$ (II) & 100 & $\mathrm{Rh}$ (II) & 10 \\
$\mathrm{Cd}$ (II) & 20 & $\mathrm{~Pb}$ (II) & 100 \\
$\mathrm{Co}$ (II) & 100 & $\mathrm{Ag}$ (I) & 50 \\
$\mathrm{Ca}$ (II) & 10 & $\mathrm{Sb}$ (III) & 50 \\
$\mathrm{Si}$ (IV) & 200 & $\mathrm{Te}$ (IV) & 10 \\
$\mathrm{Mg}$ (II) & 20 & $\mathrm{Cr}$ (III) & 100 \\
$\mathrm{Mn}$ (II) & 5 & $\mathrm{Zn}$ (II) & 10 \\
$\mathrm{Cu}$ (II) & 3 & & \\
\hline
\end{tabular}

It was found that copper and antimony already in 1:1 ratio interfered at the determination of osmium with thiopyrine, all other ions did not interfere at this process. The interfering effect of copper was masked with $0.03 \mathrm{~g}$ of ascorbic acid. The determination of osmium in a mixture simulating the composition of a platinum sponge was carried out by the method of additions. 
Graphic option. $2.20 \mu \mathrm{g}$ Os (corresponds to $7.3 \cdot 10^{-2} \%$ Os), $5 \mathrm{ml}$ of $8.7 \mathrm{M} \mathrm{H}_{3} \mathrm{PO}_{4}, 5 \mathrm{ml}$ of $6.4 \mathrm{M}$ $\mathrm{CCl}_{3} \mathrm{COOH}, 30 \mathrm{mg}$ of thiopyrine, $0.03 \mathrm{~g}$ of ascorbic acid to mask copper, $0.8 \mathrm{ml}$ of a mixture containing $3.0 \mathrm{mg}$ Pt were placed in a $15 \mathrm{ml}$ volumetric tube. The osmium content was gradually increased by addition of $5.0,15.0 ; 25.0$ and $35.0 \mu \mathrm{g}$ to the next 4 volumetric tubes, respectively. The comparison solution contained all the starting components except osmium.

The absorbance of the extracts was measured at $\lambda=728 \mathrm{~nm}$ after complete phase separation. The graph was built in the $\mathrm{A}-\omega_{\mathrm{O}} \%$ coordinates, plotting the absorbance of the extract of the analyzed model solution on the ordinate axis without additional osmium. The absolute value of the segment $\oplus_{x}$, cut off on the ordinate axis, corresponds to $\omega_{\mathrm{Os}}=7.5 \cdot 10^{-2} \%$ in the mixture.

Estimated option. The above amounts of phosphoric acid, trichloroacetic acid, thiopirine and mixture, as well as $15.0 \mu \mathrm{g}$ of osmium (additive) were placed in 2 volumetric tubes with a capacity of $15 \mathrm{ml}$.

The calculation was carried out according to the formula:

$$
\omega_{x=} \frac{A_{x}}{A_{x+d}-A_{x}} \cdot \omega_{d},
$$

where $\omega_{x}$ is the mass fraction of osmium in the mixture, $\%$; $\omega_{d}$ is the mass fraction of osmium supplement, $\% ; A_{x}$ is the absorbance of the extract with a complex of thiopyrine with osmium extracted from a model mixture of a platinum sponge; $A_{x+d}$ is the absorbance of the extract with the addition of osmium.

Determination of osmium in the model mixture of platinum sponge is show in Table 3.

T a b l e 3

Determination of osmium in the model mixture of platinum sponge

\begin{tabular}{|c|c|c|c|}
\hline Content of Os, $\omega, \%$ & Found by graphic option, $\omega, \%$ & Found by estimated option, $(\omega \pm \delta), \%$ & $\mathrm{~s}_{\mathrm{r}}$ \\
\hline $7,3 \cdot 10^{-2}$ & $7,5 \cdot 10^{-2}$ & $(7,3 \pm 0,2) \cdot 10^{-2}$ & 0,02 \\
\hline
\end{tabular}

The content of Os obtained by graphical and estimated options of the additive method is consistent with each other.

\section{Conclusions}

So the well-known extraction-photometric method for determining osmium was modified by replacing the traditional extraction system with chloroform, as an organic solvent, to a layering system with water as a single liquid component. It allowed to exclude the toxic organic solvent from the system. The optimal conditions for the extraction of osmium were selected: $21.8 \mathrm{mmol}$ TCAA, $16.0 \mathrm{mmol} \mathrm{H}_{3} \mathrm{PO}_{4}, 0.15 \mathrm{mmol}$ thiopyrine. A linear relationship was observed when 2 to $40 \mu \mathrm{g}$ of osmium introduced into the system. The results of the developed methodology for the determination of osmium with thiopyrine were presented by the example of a model mixture corresponding to the composition of a platinum sponge. The interfering effect of $\mathrm{Al}$ (III), B (III), Bi (III), Fe (III), Au (III), Ir (II), Cd (II), Co (II), Ca (II), Si (IV), Mg (II), Mn (II), Cu (Il), Mo (VI), As (V), Ni (II), Sn (IV), Pd (II), Rh (II), Pb (II), Ag (I), Sb (IIl), Te (IV), Cr (III), Zn (II) contained in a platinum sponge was investigated. The interfering effect of copper has been established, which is eliminated by masking with ascorbic acid.

\section{References}

1 Лосев В.Н. Сорбционно-фотометрическое определение осмия после его выделения из газовой фазы силикагелем, химически модифицированным меркаптогруппами / В.Н. Лосев, И.П. Бахвалова, Ю.В. Кудрина, А.К. Трофимчук // Журн. общ. хим. - 2004. - Т. 74, № 8. - С. 796-799.

2 Barnard C.F.J. Oxidation States of Ruthenium and Osmium / C.F.J. Barnard // Platinum Metals Review. — 2004. — Vol. 48. - P. 157. - DOI:10.1595/147106704X10801

3 Ливингстон С. Химия платиновых металлов / С. Ливингстон. - М.: Мир, 1972. - 366 с.

4 Радушев А.В. Спектрофотометрические методы определения осмия, рутения, золота / А.В. Радушев, Г. Аккерман // Заводск. лаб. — 1978. — Т. 35, № 12. — С. 1431-1433.

5 Воробьева Р.С. Гигиена и токсичность кадмия / Р.С. Воробьева. - М.: Науч. обзор, 1979. - 184 с.

6 Акимов В.К. Тиопирин и его некоторые производные как аналитические реагенты на осмий / В.К. Акимов, А.И. Бусев, Л.Я. Клиот // Журн. аналит. хим. — 1977. — Т. 32, № 5. — С. 1004-1008.

7 Булатов М.И. Практическое руководство по фотоколориметрическим и спектрофотометрическим методам анализа / М.И. Булатов, И.П. Калинкин. - М.: Химия, 1976. — С. 376. 


\title{
Л.С. Егорова, Е.А. Лейтес \\ «Су - тиопирин - трихлорацетикалық және ортофосфор қышқылы» төрттік жүйесінің көмегімен осмийді экстракциялық-фотометриялық анықтау
}

\begin{abstract}
Мақала осмийдің экстракциялық-фотометриялық анықталуына арналған. Мақсаты осмийдің экстракциялық-фотометриялық анықтамасын дәстүрлі экстракция жүйесін хлороформға органикалық еріткіш ретінде қабыршақтайтын жүйе мен бір сұйық компонент - су ауыстыру арқылы өзгерту болды. Бұл жүйе улы органикалық еріткішті жоюға мүмкіндік берді. Осмийді алудың оңтайлы шарттары қымбат реагент ретінде тиопиринді тұтынудың минималды болуын ескере отырып, таңдалды. Тиопиринмен осмийдің микрограмм мөлшерін анықтауға арналған әзірленген әдістеменің нәтижелері платина губкасының құрамына сәйкес модельді қоспаның мысалында келтірілген. Al (III), B (III), $\mathrm{Bi}$ (III), Fe (III), Au (III), Ir (II), Cd (II), Co (II), Ca (II), Si (II), Si (кедергі) әсері IV), Mg (II), Mn (II), $\mathrm{Cu}$ (II), Mo (VI), As (V), Ni (II), Sn (IV), Pd (II), Rh (II), Pb (Платина губкасында орналасқан II), Ag (I), $\mathrm{Sb}$ (III), Te (IV), Cr (III), Zn (II). Аскорбин қышқылымен маскирлеу арқылы жойылатын мыстың араласатын әсері анықталды.
\end{abstract}

Кілт сөздер: осмий, тиопирин, экстракциялық-фотометриялық анықтау, платина губкасы, комплекс түзуші, дәрілік препараттардың синтезі, кортизон.

\author{
Л.С. Егорова, Е.А. Лейтес
}

\section{Экстракционно-фотометрическое определение осмия с помощью четверной системы «вода - тиопирин - трихлоруксусная и ортофосфорная кислоты»}

\begin{abstract}
Статья посвящена экстракционно-фотометрическому определению осмия. Цель заключалась в модификации известного экстракционно-фотометрического определения осмия путем замены традиционной экстракционной системы с хлороформом в качестве органического растворителя на расслаивающуюся систему с единственным жидким компонентом - водой. Это позволило исключить из системы токсичный органический растворитель. Выбраны оптимальные условия извлечения осмия с учетом того, что расход тиопирина, как дорогостоящего реагента, должен быть минимальным. Представлены результаты разработанной методики определения микрограммовых количеств осмия с тиопирином на примере модельной смеси, соответствующей составу платиновой губки. Исследовано мешающее влияние $\mathrm{Al}$ (III), В (III), Bi (III), Fe (III), Au (III), Ir (II), Cd (II), Co (II), Ca (II), $\mathrm{Si}$ (IV), $\mathrm{Mg}$ (II), $\mathrm{Mn}$ (II), Cu (II), Mo (VI), As (V), Ni (II), Sn (IV), Pd (II), Rh (II), Pb (II), Ag (I), Sb (III), Te (IV), Cr (III), $\mathrm{Zn}$ (II), содержащихся в платиновой губке. Установлено мешающее влияние меди, которое устраняют маскированием аскорбиновой кислотой.
\end{abstract}

Ключевые слова: осмий, тиопирин, экстракционно-фотометрическое определение, платиновая губка, комплексообразование, синтез лекарственных средств, кортизон.

\section{References}

1 Losev, V.N., Bakhvalova, I.P., Kudrina, Yu.V., \& Trofimchuk, A.K. (2004). Sorbtsionno-fotometricheskoe opredelenie osmiia posle eho vydeleniia iz hazovoi fazy silikahelem, khimicheski modifitsirovannym merkaptohruppami [Sorption-photometric determination of osmium after its separation from the gas phase by silica gel chemically modified with mercapto groups]. Zhurnal obshchei khimii - Journal of General Chemistry, 74(8), 796-799 [in Russian].

2 Barnard, C.F.J. (2004). Oxidation States of Ruthenium and Osmium. Platinum Metals Review, $48,157$. doi:10.1595/147106704X10801

3 Livingston, S. (1972). Khimiia platinovykh metallov [Chemistry of Platinum Metals]. Moscow: Mir [in Russian].

4 Radushev, A.V., \& Akkerman, G. (1978). Spektrofotometricheskie metody opredeleniia osmiia, ruteniia, zolota [Spectrophotometric methods for the determination of osmium, ruthenium, gold]. Zavodskaia laboratoriia - Factory laboratory, 35(12), 14311433 [in Russian].

5 Vorobyeva, R.S. (1979). Hihiena i toksichnost kadmiia [Cadmium Hygiene and Toxicity]. Moscow: Nauchnyi obzor [in Russian].

6 Akimov, V.K., Busev, A.I, \& Kliot, L.Ya. (1977). Tiopirin i eho nekotorye proizvodnye kak analiticheskie reahenty na osmii [Thiopyrin and its some derivatives as analytical reagents for osmium]. Zhurnal analiticheskoi khimii - Journal of Analytical Chemistry, 32(5), 1004-1008 [in Russian].

7 Bulatov, M.I., \& Kalinkin, I.P. (1976). Prakticheskoe rukovodstvo po fotokolorimetricheskim i spektrofotometricheskim metodam analiza [Practical guide to Photocolorimetric and Spectrophotometric Analysis Methods]. Moscow: Khimiia [in Russian]. 